\title{
KARAKTERISTIK MORFOLOGI DAN AKTIVITAS ENZIM PROTEASE BAKTERI SIMBION NUDIBRANCH
}

\author{
(Morphological Characteristics and Activity of Protease Enzyme Bacterial \\ Symbiont Nudibranch)
}

\section{Sabrina I. Hengkengbala ${ }^{1}$, Rosita A.J Lintang ${ }^{2}$, Deiske A. Sumilat ${ }^{2}$, Remy E.P. Mangindaan ${ }^{2}$, Elvy L. Ginting ${ }^{2}$, Sipriana Tumembouw ${ }^{3}$}

1. Mahasiswa Program Studi IImu Kelautan, FPIK, UNSRAT Manado

2. Staf Pengajar Program Studi IImu Kelautan, FPIK, UNSRAT Manado

3. Staf Pengajar Program Studi Budidaya Perairan, FPIK UNSRAT Manado

Penulis korespondensi: Rosita Lintang; rositalintang@unsrat.ac.id

\begin{abstract}
One type of enzyme whose application is very widespread is protease enzymes. Microorganisms that have not been widely explored as a source of protease enzymes are bacteria that are in conjunction with Nudibranch. The study aims to identify the morphological characteristics of bacteria, then determine the hydrolysis ability of protease enzymes from bacteria symbiont Nudibranch. Identification of morphological characteristics is done macroscopic, and microscopic with gram staining. Proteolytic activity tests are performed qualitatively by measuring the proteolytic index of bacteria grown on Skim Milk Agar medium. The results of macroscopic identification of symbiotic bacteria with Nudibranch are dominated by irregular colony shapes, undulated edges, growth of the entire colony has a flat height, milky white colony color, buttery texture and opaque bacterial colonies. Based on microscopic identification, two gram-negative isolates are obtained, namely RL.S14, S1.1.1, and gram positive isolates, namely AK.S00, AK.S01, AK.S02, AK.S03, S.PP1, RL.S6, S2.1.5, S2.2.1, S3.3.1, S3.3.4, RL.S10. Nudibranch symbiont Bacterial has colony cells were dominated by the diplobacillus form. The results of the protease activity test of Nudibranch symbiont bacteria showed that 12 positive isolates had proteolytic activity with the highest proteolytic index produced by isolate AK.S00, which was $2.5 \mathrm{~mm}$.
\end{abstract}

Keywords: Nudibranch, symbiotic bacteria, characteristics, protease

\section{ABSTRAK}

Salah satu jenis enzim yang aplikasinya sangat luas adalah enzim protease. Mikroorganisme yang belum banyak dieksplorasi sebagai sumber enzim protease adalah bakteri yang bersimbion dengan Nudibranch. Penelitian ini bertujuan untuk mengidentifikasi karakteristik morfologi bakteri, kemudian menentukan kemampuan hidrolisis enzim protease dari bakteri simbion Nudibranch. Identifikasi karakteristik morfologi dilakukan secara makroskopik, dan mikroskopik dengan pewarnaan gram. Uji aktivitas proteolitik dilakukan secara kualitatif dengan mengukur indeks proteolitik bakteri yang ditumbuhkan pada media Skim Milk Agar. Hasil identifikasi secara makroskopik bakteri yang bersimbion dengan Nudibranch didominasi oleh bentuk koloni tidak beraturan, tepian bergelombang, pertumbuhan seluruh koloni memiliki ketinggian datar, warna koloni putih susu, tekstur seperti mentega dan koloni bakteri tidak tembus cahaya. Berdasarkan identifikasi secara mikroskopik didapatkan dua isolat yang bersifat gram negatif yaitu isolat RL.S14, S1.1.1, dan gram positif yaitu isolat AK.S00, AK.S01, AK.S02, AK.S03, S.PP1, RL.S6, S2.1.5, S2.2.1, S3.3.1, S3.3.4, RL.S10. Sel koloni bakteri simbion Nudibranch didominasi oleh bentuk diplobasil. Hasil uji aktivitas protease bakteri simbion Nudibranch menunjukkan 12 isolat positif memiliki aktivitas proteolitik di mana indeks proteolitik paling tinggi dihasilkan oleh isolat AK.SOO yaitu $2,5 \mathrm{~mm}$.

Kata kunci: Nudibranch, bakteri simbion, karakterisasi, protease

\section{PENDAHULUAN}

Nudibranch adalah avertebrata laut dalam kelas Gastropoda yang tidak memiliki cangkang. Secara fisik Nudibranch hanya terdiri dari kulit, otot dan organ tubuh karena telah menanggalkan cangkang pada jutaan tahun yang lalu. Kata Nudibranchia berasal dari gabungan kata bahasa Latin nudus yang berarti telanjang dan kata brankhia dari bahasa Yunani yang berarti 
insang. "Insang Telanjang" merupakan istilah yang mengarah pada organ respirasi eksternal pada organisme ini. Nudibranch merupakan karnivora yang memakan sebagian besar organisme sesil seperti spons, bryozoa, ascidia, colenterata, telur Nudibranch lain, dan beberapa jenis Nudibranch bersifat parasit (Chester dkk., 2000).

Penelitian yang dilakukan Klussmann-Kolb dan Brodie pada tahun 1999 secara tidak sengaja menemukan bakteri simbiotik pada jaringan vestibular dan massa telur Nudibranch Dendrodoris nigra, namun fungsi dari bakteri simbiotik tersebut belum diketahui. Beberapa penelitian belakangan ini kemudian menemukan bahwa Nudibranch bersimbion dengan beragam mikroorganisme seperti bakteri (Arie $d k k$., 2020; Dajoh dkk., 2020; Doringin dkk., 2020; Ukar dkk., 2020), aktinomisetes (Riyanti, 2009) dan jamur (Mahyudin, 2008). Mikroorganisme yang bersimbion dengan Nudibranch ini diduga berasal dari sumber makanan dan lingkungan Nudibranch berada.

Kebanyakan Nudibranch memiliki umur hidup yang tidak lebih dari satu tahun, kemudian lenyap tanpa meninggalkan bekas karena tubuhnya tidak memiliki rangka kapur (Holland, 2008). Hal ini menjadi masalah untuk mempelajari sejarah kehidupan dan proses evolusinya sehingga yang dapat dipelajari adalah bentuk hidupnya saat ini untuk diambil manfaatnya (Fontana $d k k$., 2000). Sejauh ini penelitian mengenai Nudibranch dan simbionnya baru sampai pada kemampuan dalam menghasilkan senyawa bioaktif berupa antioksidan (Nurjanah dkk., 2010), antikanker (Nuzzo dkk., 2012), antibakteri dan anti UV.

Protease disebut juga peptidase atau proteinase, merupakan enzim golongan hidrolase yang memecah protein menjadi molekul yang lebih sederhana, seperti menjadi oligopeptida pendek atau asam amino, dengan reaksi hidrolisis pada ikatan peptida. Penggunaan enzim dalam dunia industri semakin meluas karena adanya perkembangan dalam teknologi fermentasi, rekayasa genetika dan teknologi aplikasi enzim.
Penggunaan mikroorganisme untuk produksi enzim, khususnya protease mempunyai beberapa kelebihan, diantaranya mudah diproduksi dalam skala besar, waktu produksi relatif singkat, mudah dimanipulasi secara genetik serta dapat diproduksi secara berkesinambungan dengan biaya yang relatif rendah (Thomas, 1984) karena pertumbuhan mikroorganisme cepat dan mudah diatur serta mutu enzim yang dihasilkan lebih seragam. Diperkirakan kurang dari $2 \%$ mikroba baru berhasil diisolasi dari lingkungan laut sebagai kultur murni (Pringgenies, 2009). Adanya mikroorganisme unggul merupakan salah satu faktor penting dalam usaha produksi enzim. Protease mikroorganisme simbion organisme laut telah berhasil diperoleh dari avertebrata laut seperti teripang (Anggorowati dkk., 2019) dan spons (Andriyono dkk., 2015; Setyati $d k k$., 2016; Sembiring dkk., 2021). Mikroorganisme yang belum banyak dieksplorasi sebagai sumber enzim protease adalah bakteri yang bersimbion dengan Nudibranch.

Tujuan penelitian ini untuk mengidentifikasi karakteristik morfologi bakteri simbion Nudibranch yang memiliki potensi sebagai penghasil enzim protease dan menentukan kemampuan hidrolisis enzim protease dari bakteri simbion Nudibranch dengan Indeks Proteolitik.

\section{METODE PENELITIAN}

\section{Pengambilan dan Identifikasi Sampel}

Isolat bakteri simbion Nudibranch yang digunakan dalam penelitian ini diperoleh dari Laboratorium Biologi Molekuler dan Farmasitika Laut, Fakultas Perikanan dan IImu Kelautan, Universitas Sam Ratulangi Manado. Bakteri yang digunakan telah diisolasi, dilakukan pemurnian lalu disimpan sebagai stok pada media nutrient agar miring. Sampel Nudibranch yang digunakan diperoleh dari beberapa perairan yaitu perairan Buloh Tateli, Malalayang Manado, Pulau Bangka Likupang, dan Pangalisang Bunaken. Untuk peta lokasi pengambilan sampel dapat dilihat pada gambar 1 . 


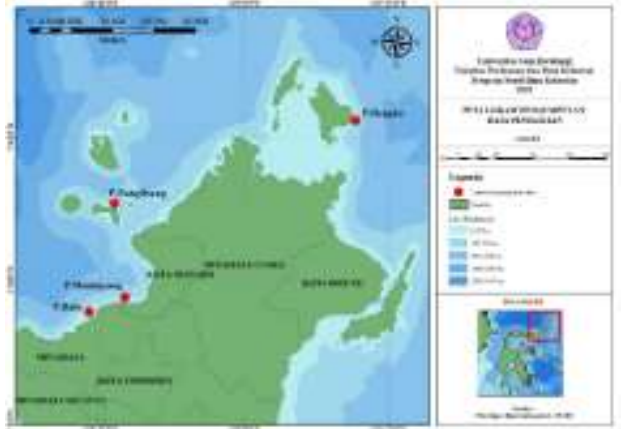

Gambar 1. Peta Lokasi Pengambilan Sampel

Organisme Nudibranch yang diperoleh telah diidentifikasi secara morfologi. Identifikasi dilakukan dengan mengamati warna, bentuk, ukuran tubuh, keberadaan tuberkel, rhinophore, insang, pola garis pada tubuh, pola warna, dan bentuk tubuh dipandu menggunakan buku "Nudibranch \& Sea Slug Identification" (Gosliner dkk., 2015) dan dilengkapi dengan informasi penunjang dari website WoRMS dan Sea Slug Forum.

\section{Sterilisasi Alat dan Bahan}

Alat yang akan digunakan berupa cawan petri, erlenmeyer, dan peralatan kaca lainnya dicuci bersih, kemudian disterilisasi menggunakan oven dengan suhu $160^{\circ} \mathrm{C}$ selama \pm 120 menit, sedangkan alat-alat seperti jarum ose disterilkan dengan pemanasan api langsung. Untuk sterilisasi bahan seperti media Nutrient Agar dilakukan dengan cara dimasukkan ke dalam autoclave pada suhu $121^{\circ} \mathrm{C}$ selama \pm 15 menit dengan tekanan $1 \mathrm{~atm}$. Untuk media Skim Milk disterilisasi dengan cara dimasukkan ke dalam autoclave dengan suhu $108^{\circ} \mathrm{C}$ selama 8 menit.

\section{Pembuatan Media Nutrient Agar (NA)}

Pembuatan media NA menggunakan bahan 5,6 gram NA, 1 gram agar, dan air laut saring $50 \%$ sebanyak $200 \mathrm{ml}$. Bahan yang sudah ditimbang kemudian dimasukkan ke dalam erlenmeyer lalu ditutup menggunakan alumunium foil dan diaduk hingga homogen, setelah itu disterilisasi menggunakan autoklaf pada suhu $121^{\circ} \mathrm{C}$ selama \pm 15 menit. Setelah media steril, media dituang ke cawan petri secara aseptis dan dibiarkan hingga keras.

\section{Penyegaran Isolat Bakteri}

Penyegaran atau peremajaan isolat bakteri dilakukan dengan memanaskan jarum ose hingga memijar di atas lampu bunsen, kemudian dibiarkan dingin. Biakan bakteri diambil menggunakan jarum ose kemudian digoreskan pada permukaan media NA dengan pola zigzag secara vertikal. Selesai proses penyegaran bakteri tersebut pada media NA, panaskan petri pada setiap sisinya menggunakan lampu bunsen dan tutup setiap sisi dari petri dengan menggunakan plastik wrap. Setiap petri diberi label, lalu diinkubasi selama 1x24 jam pada suhu $37^{\circ} \mathrm{C}$.

\section{Pemurnian Isolat Bakteri}

Bakteri yang telah diremajakan dan diinkubasi selama 24 jam kemudian dikultur dengan metode gores (streak plate method). Metode gores digunakan untuk mengkultur koloni bakteri. Hal ini dilakukan agar mendapatkan koloni terpisah yang merupakan biakan murni. Metode ini dilakukan dengan menggoreskan satu ose bakteri pada permukaan media NA dalam cawan petri dengan pola goresan kuadran. Metode ini dilakukan secara berulang-ulang hingga mendapatkan koloni terpisah (koloni tunggal).

\section{Identifikasi Morfologi Koloni Bakteri}

Pengamatan makroskopik bakteri pada media NA dalam cawan petri meliputi bentuk, warna, elevasi, bagian tepi, tekstur dan optikal koloni. Pengamatan mikroskopik dilakukan dengan melihat bentuk dan warna sel yang telah dilakukan metode pewarnaan gram di bawah mikroskop.

\section{Pembuatan media Skim Milk Agar (SMA)}

Sebanyak 0,5 gram nutrient agar ditimbang dan dituang ke dalam erlenmeyer lalu ditambahkan agar sebanyak 2 gram kemudian ditambahkan 
akuades $150 \mathrm{ml}$. Media NA disterilisasi menggunakan autoclave pada suhu $121^{\circ} \mathrm{C}$ selama \pm 15 menit. Setelah itu, susu skim ditimbang sebanyak 1 gram dan dituang ke dalam erlenmeyer lalu ditambahkan akuades $50 \mathrm{ml}$. Susu skim disterilisasi tersendiri menggunakan autoclave, setelah steril dituangkan ke dalam media NA secara aseptis, aduk hingga homogen dan media dituang ke cawan petri.

\section{Uji Aktivitas Proteolitik}

Untuk mengetahui isolat bakteri yang memiliki aktivitas enzim protease, dilakukan uji kualitatif. Koloni bakteri diambil menggunakan jarum ose steril, kemudian ditanam pada media Skim milk agar secara aseptis dengan cara ditotolkan. Selesai proses penanaman bakteri tersebut pada media SMA, panaskan setiap sisi petri menggunakan lampu bunsen kemudian bungkus petri menggunakan plastik wrap lalu inkubasi pada suhu ruangan selama 1×24 jam.
Aktitivas enzim protease dapat dilihat dengan adanya zona bening yang terbentuk pada media skim milk agar. Selanjutnya koloni bakteri diamati dan diukur pertumbuhan dan zona beningnya menggunakan mistar. Uji aktivitas enzim protease secara kualitatif dilakukan dengan menghitung Indeks Proteolitik pada media Skim Milk Agar. Perhitungan indeks proteolitik (IP) merupakan perbandingan diameter zona bening dengan diameter koloni bakteri (Durham dkk., 1987) dengan rumus seperti berikut :

$I P=\frac{\text { diameter zona bening }}{\text { diameter koloni }}$

\section{HASIL DAN PEMBAHASAN}

\section{Identifikasi Sampel}

Secara keseluruhan terdapat lima spesies Nudibranch yang diambil dari empat lokasi perairan. Pada Tabel 1 dapat dilihat masing-masing asal dan kode isolat beserta nama spesies Nudibranch yang digunakan.

Tabel 1. Spesies, Kode dan Asal Lokasi Isolat Bakteri Simbion Nudibranch

\begin{tabular}{|c|c|c|c|}
\hline No. & Spesies Nudibranch & Kode Isolat & Lokasi Perairan \\
\hline 1 & Thuridilla lineolata & AK.SO0 & \multirow{4}{*}{ Buloh (Tateli) } \\
\hline 1. & imumana imeorala & AK.S03 & \\
\hline \multirow{4}{*}{2.} & & AK.S01 & \\
\hline & Phyllidialla nuctulaca & AK.S02 & \\
\hline & r myاmatiad pusturosa & S2.1.5 & \multirow{5}{*}{$\begin{array}{l}\text { Pangalisang } \\
\text { (Bunaken) }\end{array}$} \\
\hline & & S2.2.1 & \\
\hline 3. & Chromodoris sp. & S1.1.1 & \\
\hline \multirow{3}{*}{4.} & \multirow{3}{*}{ Phyllidia varicosa } & S3.3.1 & \\
\hline & & S3.3.4 & \\
\hline & & RL.S10 & Bangka (Likupang) \\
\hline 5. & Phyllidia picta & $\begin{array}{c}\text { S.PP1 } \\
\text { RL.S6 } \\
\text { RL.S14 }\end{array}$ & $\begin{array}{l}\text { Malalayang } \\
\text { (Manado) }\end{array}$ \\
\hline
\end{tabular}

\section{Penyegaran Isolat Bakteri Simbion Nudibranch}

Peremajaan biakan ini bertujuan untuk menyelamatkan isolat bakteri dari kontaminasi oleh bakteri lain dan memberikan penyegaran nutrien yang dibutuhkan untuk pertumbuhan bakteri (Machmud, 2001). Gambar 2 menunjukkan isolat bakteri yang disegarkan dalam media NA yang mengandung $50 \%$ air laut. 

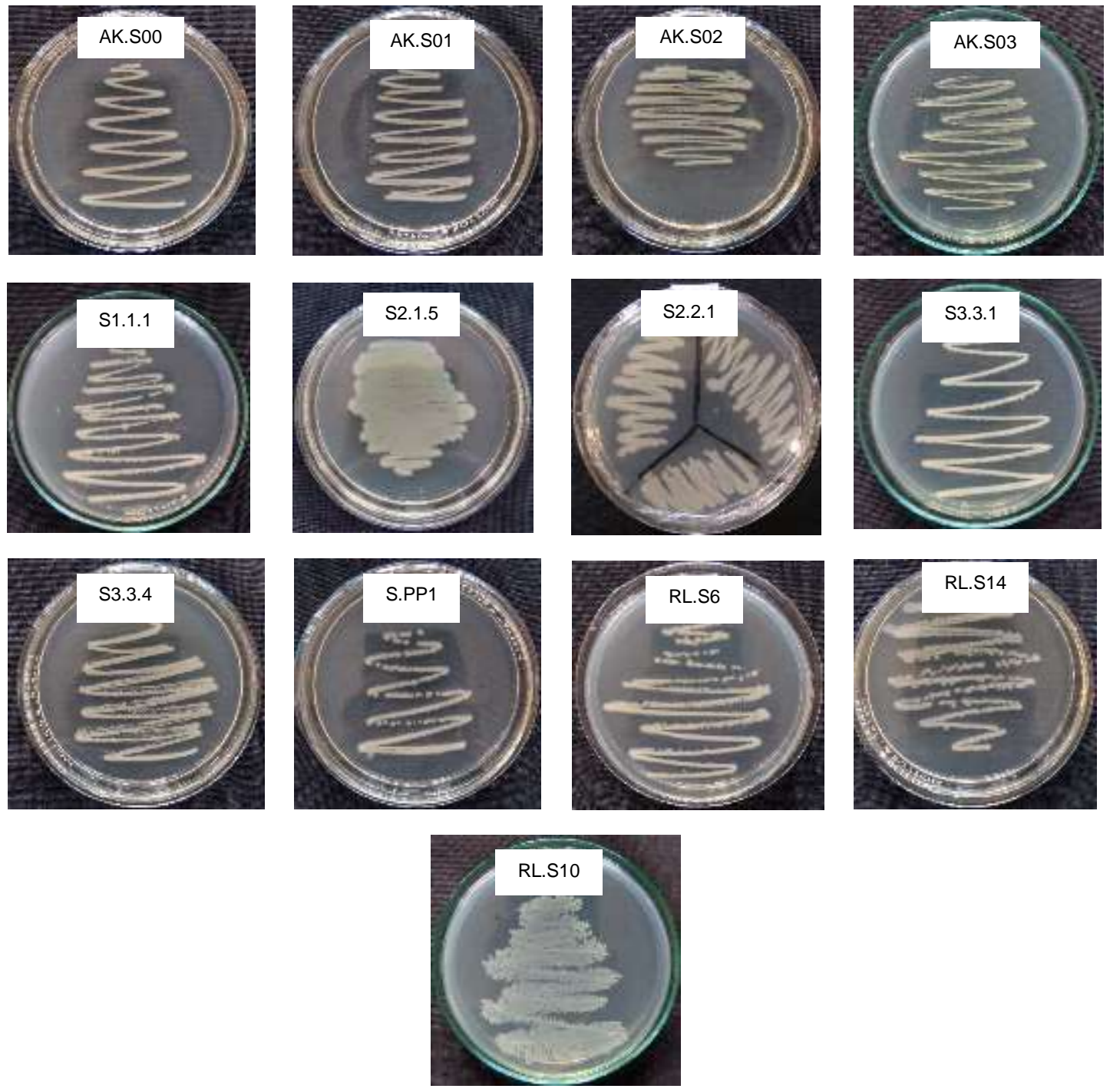

Gambar 2. Hasil Penyegaran Bakteri Simbion Nudibranch

\section{Pemurnian Isolat Bakteri}

Bakteri yang tumbuh dari peremajaan atau penyegaran tersebut kemudian langsung dikultur kuadran untuk mendapatkan koloni tunggal. Hal ini bertujuan untuk mengisolasi mikroba dari campurannya atau meremajakan kultur ke dalam media baru. Setelah diinkubasi selama 1x24 jam dengan suhu ruangan, didapatkan hasil sebagai berikut (Gambar 3). Dari pengamatan yang dilakukan terlihat adanya koloni tunggal yang muncul.
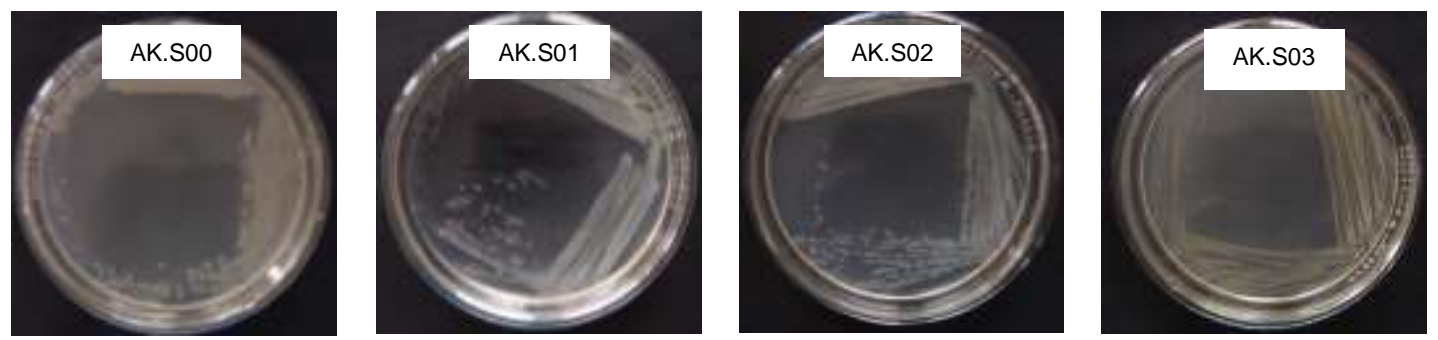

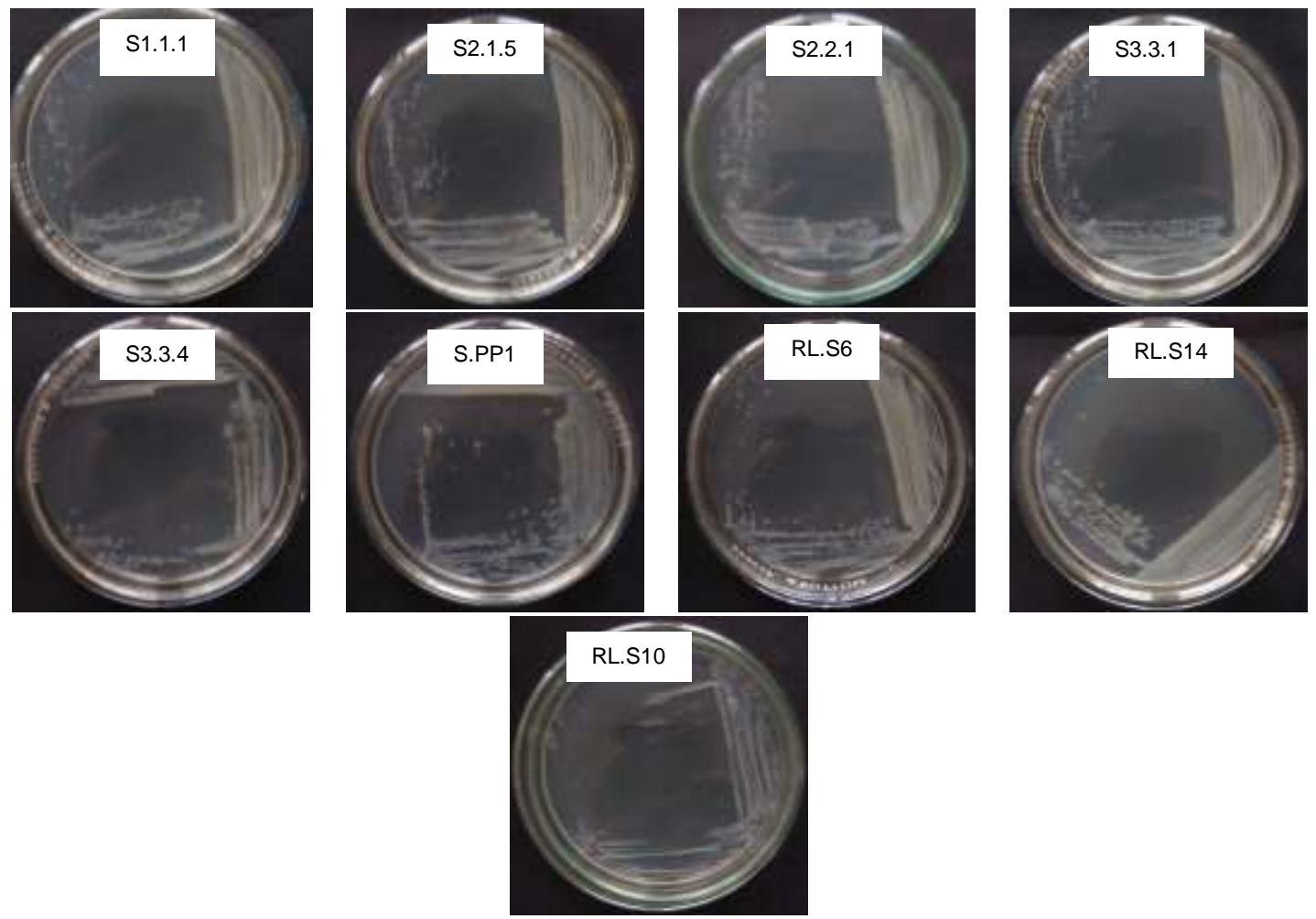

Gambar 3. Hasil Metode Gores (Streak Plate Method) Isolat Bakteri Simbion Nudibranch

\section{Identifikasi Makroskopik}

Koloni tunggal yang diperoleh pada saat pemurnian kemudian dipisahkan dan ditumbuhkan kembali pada media yang baru dan diamati pertumbuhannya. Jika koloni tersebut sudah murni dapat ditandai dengan kesamaan bentuk dan warna dari isolat murni bakteri tersebut. Bakteri yang berhasil diisolasi memiliki ciri-ciri morfologi koloni yang berbeda-beda. Ciri-ciri morfologi koloni bakteri yang berhasil diisolasi dapat dilihat pada Gambar 4. Karakterisasi morfologi koloni bakteri ini dipandu dengan menggunakan buku "Microbiology: A laboratory manual" (Cappuccino dan Welsh, 2017).
AK.SO0

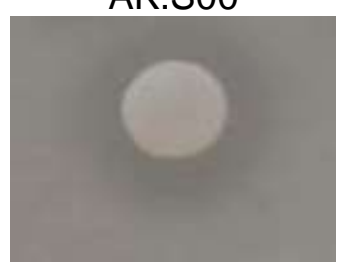

Bentuk : Bulat Tepian : Rata

Ketinggian : Datar Warna : Putih

Tekstur : Seperti mentega Optikal : Tidak tembus cahaya AK.S03
AK.S01

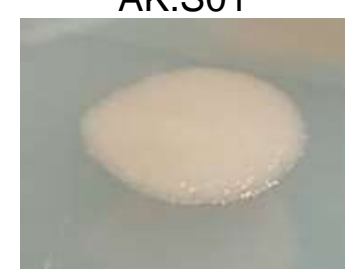

Bentuk : Tidak Beraturan Tepian : Bergelombang Ketinggian : Datar Warna : Putih susu Tekstur : Seperti mentega Optikal : Tidak tembus cahaya S1.1.1
AK.S02

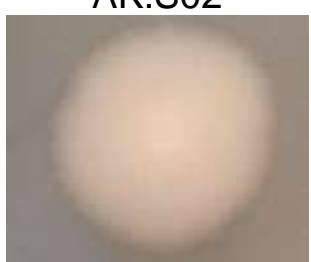

Bentuk : Tidak Beraturan Tepian : Bergelombang Ketinggian : Datar Warna : Putih susu Tekstur: Seperti mentega Optikal : Tidak tembus cahaya S2.1.5 


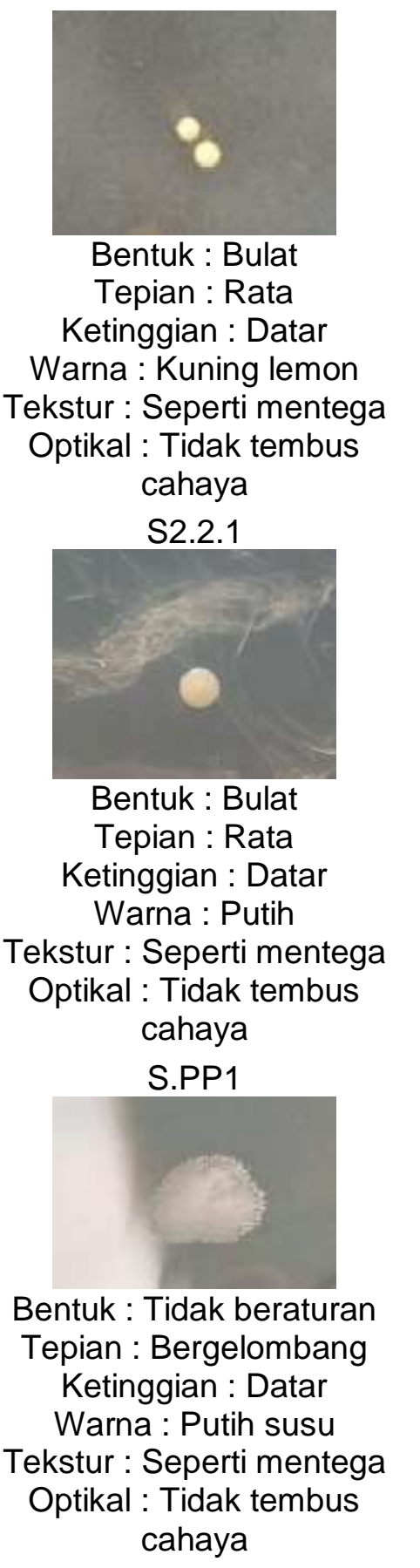

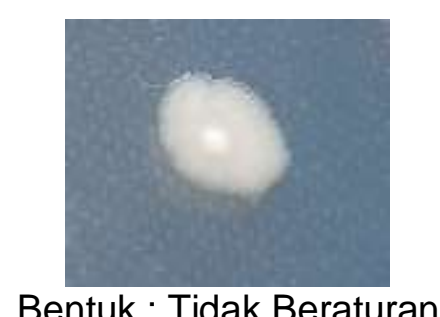

Bentuk : Tidak Beraturan

Tepian : Bergelombang

Ketinggian : Datar

Warna : Putih susu

Tekstur : Seperti mentega

Optikal : Tidak tembus cahaya S3.3.1

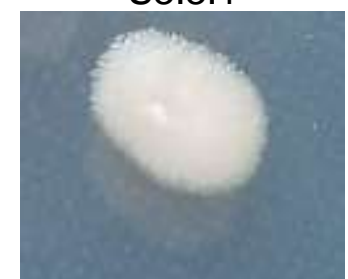

Bentuk : Tidak Beraturan

Tepian : Bergelombang

Ketinggian : Datar

Warna : Putih susu

Tekstur : Seperti mentega

Optikal : Tidak tembus cahaya

RL.S6

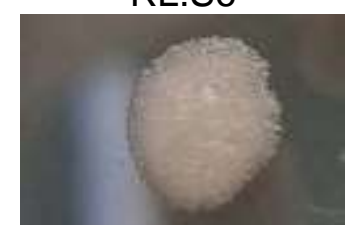

Bentuk : Tidak beraturan

Tepian : Bergelombang

Ketinggian : Datar

Warna : Putih susu

Tekstur : Seperti mentega

Optikal : Tidak tembus cahaya

RL.S10

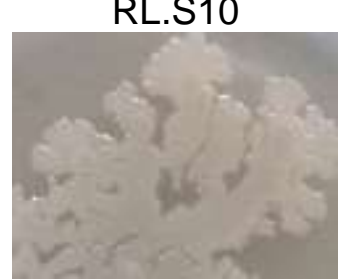

Bentuk : Tidak Beraturan

Tepian : Bergelombang Ketinggian : Datar

Warna : Putih susu

Tekstur : Seperti mentega

Optikal : Tidak tembus cahaya S3.3.4

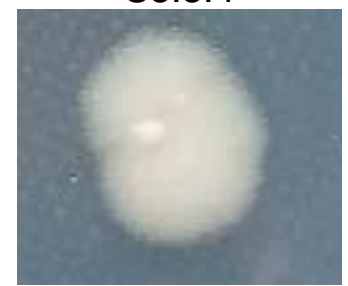

Bentuk : Tidak Beraturan

Tepian : Bergelombang Ketinggian : Datar Warna : Putih susu

Tekstur : Seperti mentega

Optikal : Tidak tembus cahaya RL.S14

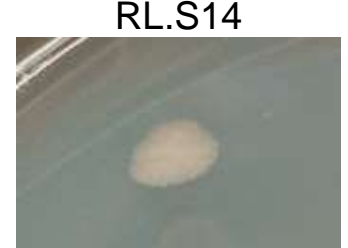

Bentuk : Tidak beraturan

Tepian : Bergelombang Ketinggian : Datar Warna : Putih susu Tekstur : Seperti mentega

Optikal : Tidak tembus cahaya

Bentuk : Seperti akar/pertumbuhan menyebar

Tepian : Berlekuk

Ketinggian : Datar

Warna : Putih susu

Tekstur : Kering

Optikal : Tidak tembus cahaya 


\section{Gambar 4. Karakterisasi Morfologi Isolat Murni Bakteri Simbion Nudibranch Secara Makroskopis}

Hasil dari identifikasi secara makroskopik didapati bahwa koloni didominasi oleh bentuk tidak beraturan, tepian bergelommbang, ketinggian datar, warna koloni putih susu, tekstur seperti mentega dan tidak tembus cahaya. Identifikasi bakteri simbion Nudibranch secara makroskopik juga dilakukan oleh Arie dkk., (2020) dan Doringin dkk., (2020) dengan bentuk, ketinggian, dan warna koloni yang hampir sama.

\section{Identifikasi Bakteri Secara Mikroskopik}

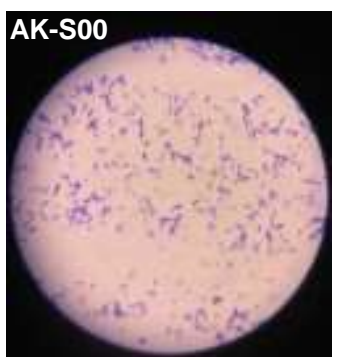

Bentuk:

Monobasil

Gram : Positif

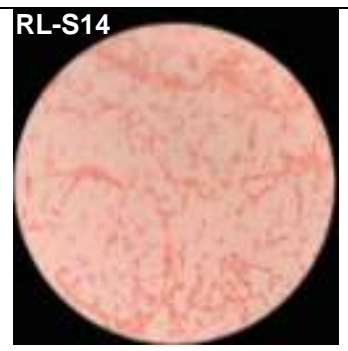

Bentuk : Diplobasil

Gram : Negatif

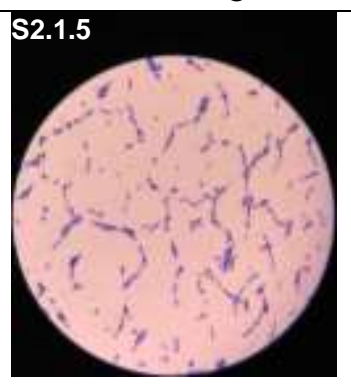

Bentuk : Diplobasil

Gram : Positif

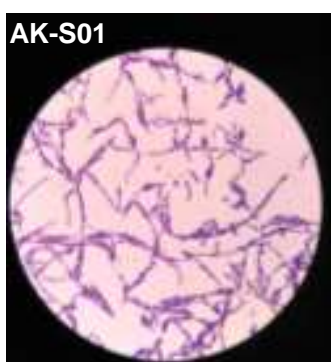

Bentuk: Streptobasil Gram : Positif

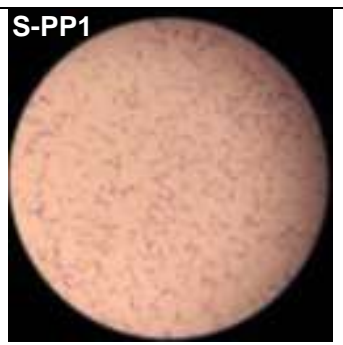

Bentuk : Diplobasil

Gram : Positif

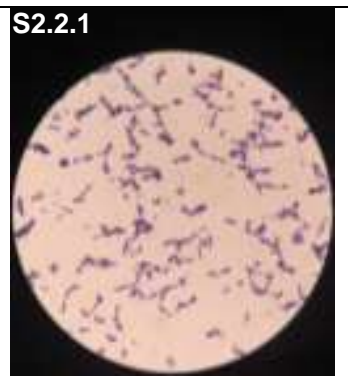

Bentuk : Diplobasil Gram : Positif
Identifikasi

bakteri

secara mikroskopik melalui pewarnaan gram ini bertujuan untuk membedakan dua kelompok besar bakteri, yaitu gram positif dan gram negatif, selain itu identifikasi secara mikroskopik dilakukan untuk melihat bentuk sel bakteri di bawah mikroskop. Dari hasil pewarnaan gram dan pengamatan yang dilakukan didapati hasil sebagai berikut (Gambar 5).

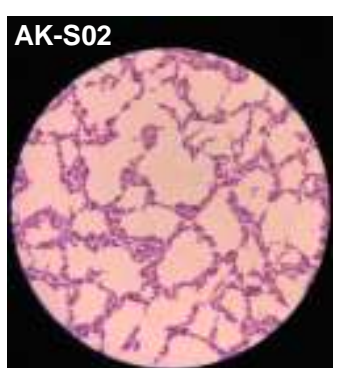

Bentuk:

Monobasil

Gram : Positif

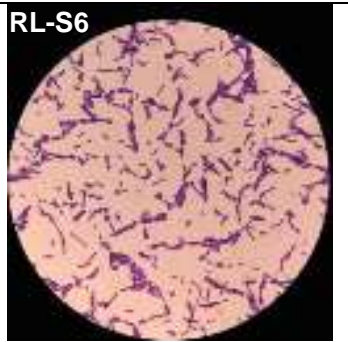

Bentuk : Diplobasil

Gram : Positif

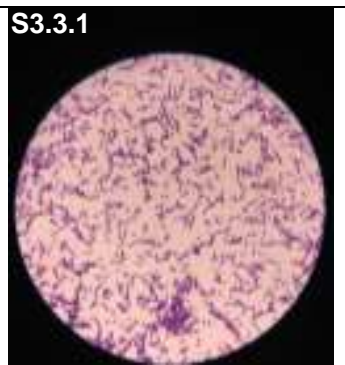

Bentuk : Diplobasil

Gram : Positif

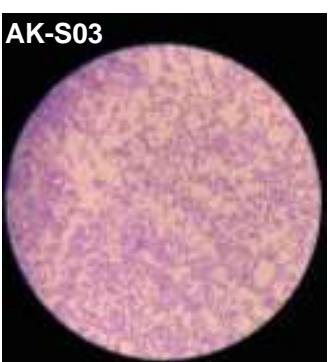

Bentuk :

Monobasil

Gram : Positif

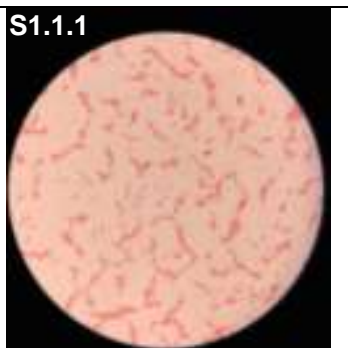

Bentuk : Diplobasil

Gram : Negatif

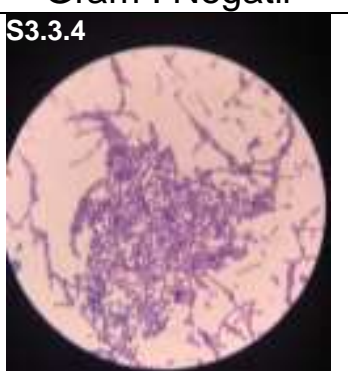

Bentuk:

Monobasil

Gram : Positif 


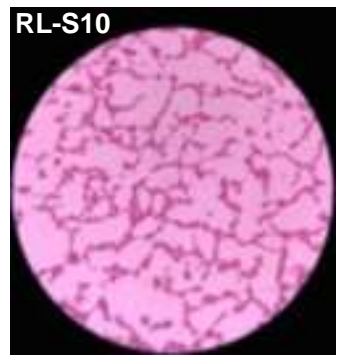

Bentuk : Diplobasil

Gram : Positif

Gambar 5. Karakterisasi Morfologi Bakteri Simbion Nudibranch Secara Mikroskopis Melalui Pewarnaan Gram

Dari pengamatan secara mikrsokopik, terdapat 11 isolat yang merupakan bakteri gram positif yaitu AK.S00, AK.S01, AK.S02, AK.S03, S.PP1, RL.S6, S2.1.5, S2.2.1, S3.3.1, S3.3.4, RL.S10, dan bakteri gram negatif yaitu RL.S14 dan S1.1.1. Sel isolat bakteri simbion Nudibranch memiliki bentuk monobasil, diplobasil, dan streptobasil. Identifikasi morfologi secara mikroskopik menggunakan pewarnaan gram pada bakteri simbion Nudibranch sebelumnya juga dilakukan oleh Doringin dkk., (2020) dengan hasil yaitu didominasi oleh bakteri gram negatif dengan bentuk sel berupa monobasil.

Beberapa jenis bakteri berbentuk batang (basil) yang dijumpai di air laut mampu menghasilkan enzim ekstraseluler yang dapat menghidrolisis protein dan polisakarida kompleks. Spesies Bacillus sangat cocok untuk produksi enzim, kecuali B. cerus dan B. anthracis. Mikroba jenis Bacillus tidak menghasilkan toksin, mudah ditumbuhkan dan tidak memerlukan substrat yang mahal (Noviasari, 2013).

\section{Uji Aktivitas Proteolitik Bakteri Simbion Nudibranch}

Isolat murni bakteri kemudian diuji aktivitas proteolitiknya. Pada gambar 6, dapat dilihat adanya aktivitas proteolitik dari bakteri simbion Nudibranch dengan terbentuknya zona bening di sekitar koloni bakteri yang tumbuh di media Skim Milk Agar.
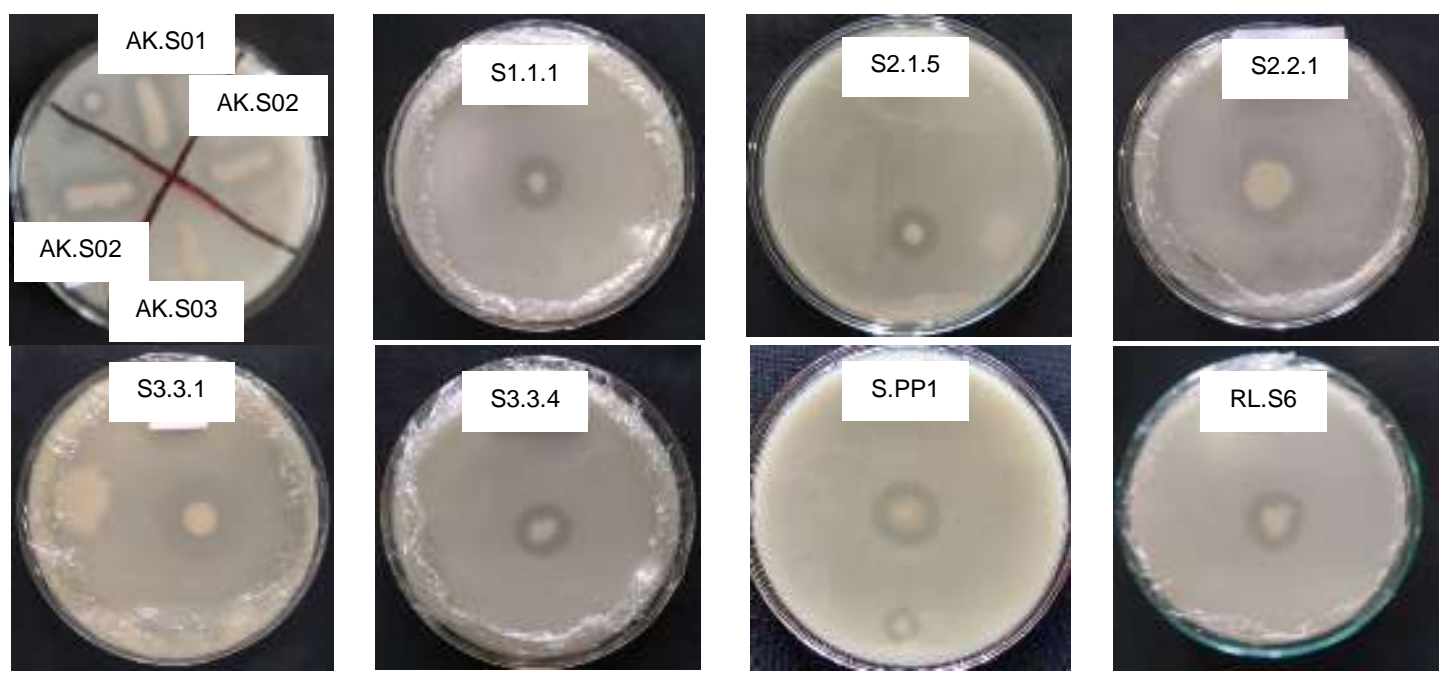


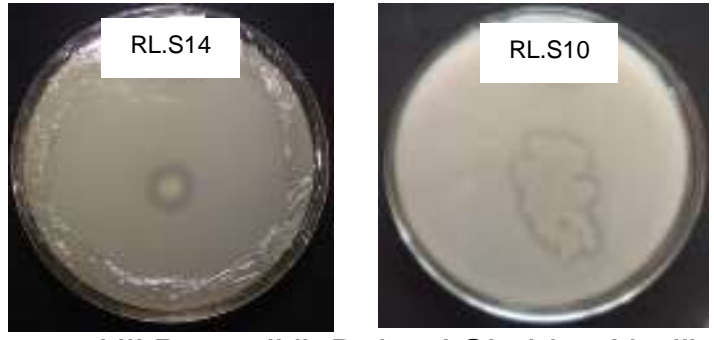

Gambar 6. Uji Proteolitik Bakteri Simbion Nudibranch

Hasil uji aktivitas proteolitik pada isolat bakteri simbion Nudibranch setelah diinkubasi selama $1 \times 24$ pada suhu ruangan menunjukkan 12 isolat bakteri bersifat proteolitik (Tabel 2). Hasil positif ditunjukkan dengan adanya zona bening di sekitar koloni. Zona bening yang terbentuk di sekitar koloni bakteri menunjukkan bahwa enzim protease yang dihasilkan dari bakteri proteolitik mampu mendegradasi substrat yang mengandung kasein yang terdapat pada media skim milk agar secara kualitatif.

Tabel 2. Perhitungan Indeks Proteolitik Bakteri Simbion Nudibranch

\begin{tabular}{ccccc}
\hline No. & $\begin{array}{c}\text { Kode } \\
\text { Isolat }\end{array}$ & $\begin{array}{c}\text { Diameter Zona Bening } \\
(\mathrm{mm})\end{array}$ & $\begin{array}{c}\text { Diameter Koloni } \\
(\mathrm{mm})\end{array}$ & $\begin{array}{c}\text { Indeks Proteolitik } \\
(\mathrm{mm})\end{array}$ \\
\hline 1. & AK.S00 & 1,5 & 0,6 & 2,5 \\
2. & AK.S01 & 1,2 & 0,6 & 2 \\
3. & AK.S02 & 1,4 & 0,7 & 2 \\
4. & AK.S03 & - & 0,6 & - \\
5. & S1.1.1 & 1,4 & 0,7 & 2 \\
6. & S2.1.5 & 1,8 & 0,8 & 2,2 \\
7. & S2.2.1 & 1,4 & 1,1 & 1,2 \\
8. & S3.3.1 & 1,7 & 1 & 1,7 \\
9. & S3.3.4 & 1,7 & 0,9 & 1,8 \\
10. & S.PP1 & 1,8 & 1,1 & 1,6 \\
11. & RL.S6 & 1,8 & 1 & 1,8 \\
12. & RL.S14 & 1,7 & 0,7 & 2,4 \\
13. & RL.S10 & 2 & 1,5 & 1,3 \\
\hline
\end{tabular}

Penghitungan indeks proteolitik dilakukan pada masing-masing isolat bakteri simbion Nudibranch. Kemampuan hidrolisis protein dari bakteri simbion Nudibranch ditandai dengan nilai Indeks Proteolitik yang merupakan perbandingan antara diameter zona bening terhadap diameter koloni isolat bakteri pada media Skim Milk Agar. Protease yang dihasilkan oleh bakteri proteolitik dapat beranekaragam tergantung dari spesies, komposisi media dan kondisi pertumbuhannya. Hasil tersebut dinyatakan sebagai aktivitas relatif protease (Sastono dkk., 2008).

Pengukuran Indeks Proteolitik dari 13 isolat bakteri simbion Nudibranch membuktikan adanya perbedaan Indeks Proteolitik yang dimiliki oleh masingmasing isolat. Hasil pengukuran Indeks
Proteolitik yang berhasil diukur termasuk dalam kategori rendah $(<2,1 \mathrm{~mm})$ sampai sedang (2,1-3,1 mm) (Ahmad dkk., 2013). Indeks Proteolitik bakteri simbion Nudibranch yang tergolong sedang adalah koloni bakteri dengan kode isolat AK.SOO, RL.S14 dan S2.1.5 sedangkan isolat bakteri yang memiliki Indeks Proteolitik yang rendah adalah bakteri dengan kode isolat AK.S01, AK.S02, RL.S6, S.PP1, S1.1.1, S2.2.1, S3.3.1, S3.3.4, dan RL.S10. Isolat bakteri yang tidak menunjukkan adanya aktivitas proteolitik adalah bakteri dengan kode isolat AK.S03. Isolat bakteri simbion Nudibranch yang memiliki Indeks Proteolitik tertinggi adalah koloni bakteri dengan kode isolat AK.SOO yaitu 2,5 $\mathrm{mm}$ dan yang memiliki Indeks Proteolitik paling rendah adalah koloni 
bakteri dengan kode isolat $S 2.2 .1$ yaitu 1,2 $\mathrm{mm}$.

Indeks proteolitik dari bakteri simbion avertebrata laut memiliki nilai yang berbeda-beda. Pengukuran indeks proteolitik bakteri simbion spons Dragmacidon sp., yang dilakukan Sembiring $d k k .$, (2021) berkisar antara 1,3 $\mathrm{mm}$ sampai 3,1 $\mathrm{mm}$. Bakteri dari sedimen dan saluran pencernaan teripang hitam Holothuria atra (Anggorowati dkk., 2019) memiliki indeks proteolitik berkisar antara $1,1 \mathrm{~mm}$ hingga 3,1 $\mathrm{mm}$. Spesies-spesies bakteri proteolitik pada kedua organisme tersebut belum diidentifikasi, sehingga diduga variasi nilai indeks proteolitik dapat dipengaruhi oleh spesies bakteri.

\section{KESIMPULAN}

Berdasarkan hasil penelitian yang dilakukan, maka dapat disimpulkan bahwa pertama, hasil identifikasi secara makroskopik bakteri yang bersimbion dengan Nudibranch didominasi oleh bentuk koloni tidak beraturan, tepian bergelombang, pertumbuhan seluruh koloni memiliki ketinggian datar, warna koloni putih susu, tekstur seperti mentega dan koloni bakteri tidak tembus cahaya. Berdasarkan identifikasi secara mikroskopik didapatkan dua isolat yang bersifat gram negatif yaitu isolat RL.S14, S1.1.1, dan gram positif yaitu isolat AK.S00, AK.S01, AK.S02, AK.S03, S.PP1, RL.S6, S2.1.5, S2.2.1, S3.3.1, S3.3.4, RL.S10. Sel koloni bakteri simbion Nudibranch didominasi oleh bentuk diplobasil. Kedua, hasil uji aktivitas protease bakteri simbion Nudibranch menunjukkan sebanyak 12 isolat positif memiliki aktivitas proteolitik dengan indeks proteolitik paling tinggi dihasilkan oleh isolat AK.SOO yaitu $2,5 \mathrm{~mm}$.

\section{DAFTAR PUSTAKA}

Ahmad, B., Nigar, S., Shah, S.S.A., Bashir, S., Ali, J., Yousaf, S., and Bangash, J.A. 2013. Isolation and Identification of Cellulose Degrading Bacteria from municipal Waste and Their Screening For Potential Antimicrobial Activity. World Applied Scinces Journal, 27(11): 1420-1426.
Andriyono, S., Jalasena, B., Tjahtjaningsih, W., and Pramono, $\mathrm{H}$. 2015. Characterisation of Symbiotic Bacteria Isolated from Sponge Haliclona sp. Exploration and Conservation of Biodiversity. $p 110$.

Anggorowati, D.A., Munandar, H., dan Indriana, L.F. 2019. Isolasi dan Penapisan Bakteri Penghasil Enzim Protease, Selulase, dan Amilase dari Sedimen dan Saluran Pencernaan Teripang Hitam Holothuria atra. Jurnal Ilmu dan Teknologi Kelautan Tropis, 11(2): 377-386.

Arie, A.K., Lintang, R.A., Mangindaan, R.E., Windarto, A.B., Losung, F., Longdong, S.N. 2020. Isolasi Dan Skrining Aktivitas Antibakteri Dari Bakteri Simbion Nudibranchia Phyllidiella pustulosa dan Thuridilla lineolata. Jurnal Pesisir dan Laut Tropis, 8(2): 40-47.

Cappuccino, J.G., and Welsh, C.T. 2017. Microbiology: A laboratory manual. Pearson Education. 30-75.

Chester, C.M., Turner, R., Carle, M., and Harris, L.G. 2000. Life history of $A$ Hydroid-Nudibranch Association: A Discrete-Event Simulation. Veliger, 43(4): 338-348.

Dajoh, T.A.U., Bara, R.A., Angkouw, E., Ompi, M., Lintang, R.A.J., Lumenta, C. 2020. Uji Aktivitas Antibakteri dan Anti-UV Phyllidiella nigra dan Bakteri Simbiotiknya Dari Perairan Tanjung Mandolang. Jurnal Pesisir dan Laut Tropis. 8(2): 61-71.

Doringin, K.M., Lintang, R.A., dan Sumilat, D.A. 2020. Karakterisasi Dan Penapisan Aktivitas Antibakeri Isolat Bakteri Simbion Thuridilla lineolata dan Phyllidiella pustulosa. Jurnal Pesisir Dan Laut Tropis, 8(3): 27-37.

Durham, D.R., Stewart, D.B., and Stellwag, E.J. 1987. Novel Alkaline and Heat Stable Serine Proteases From Alkaliphilic Bacillus sp. Strain GX6638. Journal of Bacteriology, 169(6): 2762-2768.

Fontana, A., Cavaliere, P., Wahidulla, S., Naik, C.G., and Cimino, G. 2000. A New Antitumor Isoquinoline Alkaloid From the Marine Nudibranch Jorunna funebris. Tetrahedron, 56(37): 73057308. 
Gosliner, T. M., Valdés, Á., and Behrens, D.W. 2015. Nudibranch and Sea Slug Identification; Indo-Pacific. New World Publications: Jacksonville, USA. p 452.

Holland, J.S. 2008. Warna Warni Kehidupan. NG Indonesia edisi Juni 2008. 80-83.

Klussmann-Kolb, A. And Brodie, G.D. 1999. Internal Storage And Production Of Symbiotic Bacteria In The Reproductive System of A Tropical Marine Gastropod. Marine Biology 133: 443-447.

Machmud, M. 2001. Teknik Penyimpanan dan Pemeliharaan Mikroba. Bulettin AgroBio 4(1): 24-32.

Mahyudin, N.A. 2008. Actinomycetes and Fungi Associated with Marine Invertebrates: A Potential Source of Bioactive Compounds. p 215.

Noviasari, D. 2013. Pengaruh suhu dan $\mathrm{pH}$ terhadap aktivitas enzim protease dari Bacillus mycoides yang ditumbuhkan dalam media campuran limbah cair tahu dan dedak. Disertasi. Universitas Islam Negeri Maulana Malik Ibrahim. 72 hal.

Nurjanah, Hardjito L., Monintja D.R., Bintang M. and Agungpriyono D.R. 2010. Karakterisasi lintah laut (Discodoris sp.) sebagai Antioksidan dan Antikolesterol. Disertasi. Institut Pertanian Bogor. 95 hal.

Nuzzo, G. 2012. Chemistry of the Nudibranch Aldisa Andersoni: Structure and Biological Activity of Phorbazole Metabolites. Marine Drugs. 10: 799-1811.

Pringgenies D. 2009. Bioprospeksi Bakteri Simbion dari Gastropoda Conus miles terhadap Strain Bakteri MDR (Multi Drug Resistant). IImu Kelautan. 14(1): 42-49.

Riyanti, J.W., dan Radjasa, O.K. 2009. Isolation and Screening of Antimicrobial ProducingActinomycetes Symbionts in Nudibranch. Indonesian Journal of Biotechnology, 14(1): 1132-1138.

Sastono, U., Sutardi., dan Verdial, O.F. 2008. Opimasi Pemecahan Emulsi Kanil Dengan Cara Pendinginan Dan Pengadukan Pada Virgin Coconut Oil (VCO). Institut Pertanian Bogor.
Sea Slug Forum. 2020. Available from http://www.seaslugforum.net/. Accessed 2020

Sembiring, S.C., Warouw V., Wullur S., Bara, R.A., Salaki, M., Ginting, E.L. 2021. Isolasi dan Penapisan Bakteri Penghasil Kitinase dan Protease yang Bersimbiosis dengan Spons Dragmacidon sp. dari Teluk Manado, Sulawesi Utara. Jurnal IImiah Platax. 9(1): 123-131.

Setyati, W.A., Habibi, A.S., Subagiyo, S., Ridlo, A., Soenardjo, N., dan Pramesti, R. 2016. Skrining dan Seleksi Bakteri Simbion Spons Penghasil Enzim Ekstraseluler Sebagai Agen Bioremediasi Bahan Organik dan Biokontrol Vibriosis Pada Budidaya Udang. Jurnal Kelautan Tropis, 19(1): 11-20.

Thomas, D.B. 1984. A Textbook of Industrial Microbiology. Sinaver Associates, Sunderland, USA. p 308.

Ukar, M.A., Bara, R.A., Warouw, V., Rumengan, I.F.M., Losung, F., Salaki, M. 2020. Aktivitas Senyawa Antibakteri dan Anti-UV Dari Phyllidia varicose (Cuvier, 1804) dan Bakteri Simbionnya (Nudibranch Gastropoda) Dari Perairan Tanjung Mandolang, Minahasa. Jurnal Pesisir dan Laut Tropis. 8(2): 27-39.

World Register of Marine Species. 2020. Available from https://www.marinespecies.org. Accessed 2020. 